\title{
Analisis Kelayakan Usaha Peternakan Sapi Potong Rakyat di Kabupaten Langkat
}

Ruth Dameria Halohoa, dan Chaula Lutfia Saragih ${ }^{\mathrm{b}}$

aProgram Studi Agribisnis, Universitas Quality Berastagi; Indonesia. Email: ruthdameria28@gmail.com

bProgram Studi Agribisnis, Universitas Quality Berastagi, Indonesia. Email: chaulalutfia@yahoo.com

\section{Article Info}

\section{Article history:}

Received 20 Desember 2020

Received in revised form 4 Januari 2021

Accepted 10 Januari 2021

DOI:

https://doi.org/10.32938/ag.v6i1.1189

\section{Keywords:}

Feasibility

Beef Cattle

Smallholder Farming

\begin{abstract}
Abstrak
This study aims to determine the characteristics and feasibility of smallholder beef cattle business in Langkat Regency. This research was conducted in May 2020. The research method used was a survey method. The sampling technique used in this study was the Multistage Random Sampling Method. Respondents were beef cattle breeders who were taken randomly as many as 80 respondents. The data collection method is the method of observation and direct interviews with breeders. Methods of data analysis are descriptive and quantitative. The results show the characteristics of the breeders, namely the age of the productive age breeders, namely 40-50 years (47 people), the education level of the breeders who were mostly educated in junior high school was $48.75 \%$ and the breeding experience was 11-20 years as many as 51 people (63.75\%). . Business feasibility, namely an ROI of $27.45 \%$, is greater than the interest rate on Bank BRI's deposit interest of 4\%. NPV of IDR 452,758 is worth greater than zero. The Net BC ratio value of 1.01 is greater than 1 . IRR of $14,05 \%$, is greater than the interest rate on Bank BRI's kredit interest of $6 \%$. The conclusion of this study is that the business is declared financially feasible because it is able to generate a return on investment and the revenue received is greater than the expenditure so that the business is profitable and feasible to develop.
\end{abstract}

\section{Pendahuluan}

Indonesia merupakan negara yang berpotensi dalam pengembangan sektor agribisnis, salah satunya bidang peternakan. Pembangunan peternakan merupakan bagian yang erat dari pembangunan pertanian yang mendukung penyediaan pangan asal ternak yang bergizi. Pengembangan peternakan sangat dipengaruhi oleh pertambahan penduduk yang tiap tahun meningkat. Dimasa mendatang, permintaan produksi ternak akan terus meningkat guna memenuhi kebutuhan hewani penduduk. Salah satu jenis ternak yang memberikan kontribusi besar terhadap pemenuhan kebutuhan sumber protein hewani masyarakat adalah sapi potong (Parlindungan et al., 2017). Populasi sapi potong di Indonesia berjumlah 17.050.006 juta ekor dengan Produksi daging sapi dalam negeri adalah 403.668 ton. Kebutuhan daging Tahun 2018 sebesar 663.290 ton sementara kebutuhan daging yang masih terpenuhi sebesar $60,9 \%$ dari daging sapi didalam negeri sedangkan sisanya diambil dari import sapi. Sumatera Utara merupakan salah satu daerah dengan jumlah populasi ternak sapi potong terbanyak di Indonesia setelah Jawa Timur, Jawa Tengah, Sulawasi Selatan, NTB dan NTT ( Dinas Peternakan dan Kesehatan Hewan, 2018).

Populasi ternak di Provinsi Sumatera Utara mengalami peningkatan dari 712.106 ekor Tahun 2017 menjadi 748.133 ekor di Tahun 2018. Salah satu daerah penghasil sapi potong terbanyak di Sumatera Utara adalah Kabupaten Langkat. Kabupaten Langkat merupakan daerah yang potensial dalam pengembangan peternakan sapi potong. Populasi sapi potong Tahun 2019 sebesar 201.840 ekor dengan produksi daging sebesar 95.000 ton (Dinas Ketahanan Pangan dan Peternakan Provinsi Sumatera Utara, 2019). Hal ini merupakan kesempatan untuk memenuhi kebutuhan akan produksi daging dan peluang pengembangan usaha sapi potong di Kabupaten Langkat. Salah satu permasalahan yang dihadapi oleh peternak sapi tradisional di Kabupaten Langkat adalah produktivitas ternak sapi yang rendah. Pemeliharaan sapi dengan sistem tradisional menyebabkan kurangnya peran peternak dalam mengatur perkembangbiakan ternaknya sehingga hanya menjadikan sebagai usaha sampingan dan sebagai tabungan (Hasibuan dan Meneth Ginting, 2014)

Peternak perlu mengetahui kelayakan usaha untuk mengetahui usaha tersebut layak dijalankan atau tidak (Anis et al., 2015). Oleh karena itu perlu dilakukan analisis kelayakan usaha untuk mengetahui usaha sapi potong layak atau tidak untuk dijalankan. Tujuan penelitian ini adalah untuk mengetahui karakteristik peternak dan kelayakan usaha peternakan sapi potong rakyat di Kabupaten Langkat. 


\section{Metode}

Materi yang digunakan dalam penelitian adalah unit usaha ternak sapi potong yang dilakukan oleh peternak di Kabupaten Langkat. Penelitian dilakukan dengan metode survei. Teknik pengambilan sampel dilakukan dengan Metode Multistage Random Sampling merupakan kombinasi dari sistem random sampling dan proportionate. Jumlah responden adalah 80 peternak sebagai responden. Lokasi penelitian adalah Kecamaatan Secanggang dan Wampu. Pengumpulan data dilakukan melalui wawancara pihak-pihak terkait yang mempunyai fungsi dan tugas sesuai bidang dengan panduan kuesioner. Data yang diambil berupa data primer dan sekunder. Data primer diperoleh dari survei langsung ke lapangan dan hasil wawancara dengan menggunakan bantuan kuesioner mengenai aspek teknis dan keuangan. Data Primer diambil dari Tahun 2018-2020. Data sekunder diperoleh dari instansi pemerintah maupun non pemerintah terkait analisis data dilakukan dengan metode deskriptif dan kuantitatif yaitu metode yang menggambarkan tentang hal-hal yang berhubungan dengan judul dalam penelitian ini berupa analisis kelayakan usaha dan mentabulasi data yang diperoleh serta menghitung data tersebut, kemudian menganalisis dengan menggunakan kriteria-kriteria dalam analisis kelayakan usaha dalam aspek finansial yang meliputi ROI, NPV dan BCR (Sahala, 2016). Data tersebut ditabulasi dan dihitung serta dianalisis menggunakan kriteria usaha kelayakan (Soekardono, 2009). Cara perhitungan analisis finansial yaitu

$$
\text { ROI }=\frac{\text { laba setelah pajak }}{\text { total investasi }} \times 100 \%
$$

\section{Kaidah keputusan :}

ROI>tingkat deposito bunga bank maka usaha tersebut layak dilaksanakan karena mampu menghasilkan keuntungan.

$\mathrm{ROI}<$ tingkat deposito bunga bank maka usaha tersebut tidak layak dilaksanakan karena tidak mampu menghasilkan keuntungan

$$
\mathrm{NPV}=\sum_{t=1}^{n} \frac{B t-C_{t}}{(1+i)^{t}}
$$

Keterangan:

$$
\begin{array}{ll}
\mathrm{B}_{\mathrm{t}} & =\text { merupakan benefit sosial kotor sehubungan dengan sesuatu proyek pada tahun } \\
\mathrm{C}_{\mathrm{t}} & =\text { merupakan biaya sosial kotor sehubungan dengan proyek pada tahun } \mathrm{t} \\
\mathrm{i} & =\text { Discount factor } \\
\mathrm{n} & =\text { umur ekonomis dari pada proyek } \\
\mathrm{t} & =\text { tahun, tahun pertama adalah sebagai tahun pertama investasi atau tahun ke } 0
\end{array}
$$

\section{Kaidah Keputusan :}

NPV >0 (NPV positip) : maka usaha tersebut layak dilaksanakan, karena benefit yang diterima lebih besar daripada biaya yang dikeluarkan.

NPV $<0$ (NPV negatip): maka usaha tersebut tidak layak untuk dilaksanakan, karena biaya yang dikeluarkan lebih besar daripada benefit yang diterima.

$$
\text { Net BCR } \left.=\frac{\sum \text { Present value Benefit yang positip }}{\sum \text { Presnet Value Net Benefit yang Negatif }}\right)
$$

\section{Kaidah Keputusan}

Net BCR $>1$ : maka usaha tersebut menguntungkan dan layak beroperasi.

Net $\mathrm{BCR}<1$ : maka usaha tersebut tidak menguntungkan dan tidak layak beroperasi

$$
\mathrm{IRR}=D f \text { positif }+\left[\frac{N P V \text { positif }}{N P V \text { positif }-N P \text { Vnegatif }}\right] x j a r a k D f
$$

Kriteria :

IRR < tingkat bunga kredit bank = usaha tidak layak karena keuntungan lebih rendah dari bunga kredit bank. 
IRR > tingkat bunga kredit bank = usaha layak karena keuntungan lebih besar dari bunga kredit bank.

\section{Hasil dan Pembahasan}

3.1 Karakteristik Responden

Peternak yang dijadikan responden dalam penelitian ini adalah peternak yang memiliki sapi potong. Sebagian besar responden menjalankan usaha sapi potong sebagai pekerjaan sampingan selain bertani. Peternak memelihara secara intensif yaitu sapi dikandangkan secara terus menerus hingga sapi dijual.

Tabel 1. Karakteristik Peternak Sapi Potong di Kabupaten Langkat

\begin{tabular}{lcc}
\hline Karakteristik & Jumlah Responden (orang) & Persentase (\%) \\
Umur (Tahun) & 16 & 20 \\
$30-40$ & 47 & 58,75 \\
$40-50$ & 16 & 20 \\
$50-60$ & 1 & 1,25 \\
$>60$ & & 15 \\
Pendidikan & 12 & 48,75 \\
SD & 39 & 35 \\
SMP & 28 & 1,25 \\
SMA & 1 & 25 \\
SI & & 63,75 \\
Pengalaman Beternak & 20 & 11,25 \\
$5-10$ & 51 & 25 \\
$11-20$ & 9 & \\
$21-30$ & &
\end{tabular}

Sumber: Olah Data Primer, (2020)

\subsubsection{Usia Peternak}

Berdasarkan Tabel 1 umur responden 30-40 Tahun dengan jumlah 16 orang (20\%,), 40-50 Tahun dengan jumlah 47 orang (58,75\%), umur 50-60 Tahun dengan jumlah 16 orang (20\%) dan umur > 60 tahun dengan jumlah 1 orang $(1,25 \%)$. Sebagian besar responden berumur kurang dari 65 Tahun yang berarti responden masih dalam usia produktif untuk bekerja karena dalam usia lebih dari 15 tahun dan kurang dari 60 tahun termasuk dalam angkatan kerja. Hal ini sesuai dengan pendapat Otoluwa et al. (2015) bahwa usia yang tergolong produktif dalam artian mampu melaksanakan usahanya berada pada umur 15-60 tahun. Berdasarkan penelitian Setiadi et al. (2012) menyatakan bahwa pada usia produktif peternak akan lebih mudah mengembangkan usaha peternakan yang telah dijalankan. Pada usia produktif peternak akan lebih mudah mengembangkan usaha peternakan yang telah dijalankan.

\subsubsection{Pendidikan}

Tingkat pendidikan SD berjumlah 12 orang $(20 \%)$, SLTP berjumlah 39 orang $(48,75 \%)$ SLTA berjumlah 28 orang (35\%) dan Perguruan tinggi sebanyak 1 orang $(1,25 \%)$. Tingkat pendidikan paling banyak adalah SLTP. Tingkat pendidikan berhubungan terhadap tingkat pengetahuan. Pengetahuan mereka mengenai beternak sapi potong diperoleh dari warisan orang tua, pengalaman sendiri dan belajar dari pengalaman orang lain. Tingkat pendidikan yang dimiliki masih rendah dan pola pemeliharaan masih bersifat tradisional dengan mengikuti tradisi yang diturunkan oleh orang tua/keluarga dan peternak hanya menjadikan usaha sapi potong sebagai usaha sampingan. Tingkat pendidikan yang dimiliki oleh peternak berpengaruh terhadap kemampuan menyerap informasi yang diterima Hal ini sesuai dengan penelitian Idin (2016) yang menyatakan bahwa tingkat pendidikan berpengaruh terhadap peningkatn informasi.

\subsubsection{Pengalaman Beternak}

Pengalaman beternak dimulai dari 5-10 Tahun berjumlah 20 orang (25\%), pengalaman beternak 11-20 Tahun sebanyak 51 orang (63,75\%) pengalaman beternak 21-30 Tahun sebanyak 9 orang $(11,25 \%)$. Semakin lama pengalaman beternak maka lebih mampu mengarah pada manajemen bisnis sehingga mampu meningkatkan pendapatan petani. Berdasarkan hasil penelitian Eddy et al. (2012) yang menyatakan bahwa pengalaman mempengaruhi adopsi teknologi yang mendukung pengetahuan, sikap dan pengambilan keputusan petani bahwa pengalaman beternak yang lama akan memberikan bekal pengetahuan dan keterampilan dalam mengelola usaha ternaknya. Semakin lama beternak, cenderung semakin memudahkan peternak dalam pengambilan keputusan yang berhubungan dengan teknis pelaksanaan usaha ternaknya. 
Menurut Hastang dan Asnawi (2014) menyatakan bahwa pengalaman beternak dapat dijadikan pedoman penyesuaian terhadap permasalahan usaha ternak dimasa mendatang.

\subsection{Analisis Pendapatan Peternakan Sapi Potong Rakyat Kabupaten Langkat}

\subsubsection{Penerimaan}

Penerimaan adalah segala sesuatu yang dapat meningkatkan pendapatan sebuah proyek (Sunarto et al., 2016). Penerimaan pada usaha sapi potong berasal dari penjualan sapi. Besarnya penerimaan usaha sapi potong bergantung pada bobot hidup serta harga jual pada saat terjadi proses penjualan. Berdasarkan penelitian Widayati et al. (2018) bahwa penerimaan dalam usaha sapi potong berasal dari penjualan sapi di waktu yang tepat untuk menghasilkan keuntungan yang besar. Penerimaan yang diperoleh dari penjualan sapi potong di Kabupaten Langkat Tahun 2018 sebesar Rp 5.037.500/Tahun, Tahun 2019 sebesar Rp 11.900.000/ Tahun dan Tahun 2020 sebesar Rp 16.122.500 (Tabel 2).

Biaya Produksi yang dikeluarkan dalam Usaha Sapi Potong adalah biaya tetap dan biaya tidak tetap. Biaya tetap Tahun 2018 terdiri dari biaya penyusutan kandang sebesar Rp 362.138,00:, biaya penyusutan peralatan sebesar Rp 25.819 dan biaya listrik sebesar Rp 24.875. Total biaya tetap 2018 sebesar Rp 412.832. Biaya tetap Tahun 2019 terdiri dari biaya penyusutan kandang sebesar Rp 362.138,00:, biaya penyusutan peralatan sebesar Rp 25.819 dan biaya listrik sebesar Rp 27.875. Total biaya tetap sebesar Rp 415.832. Biaya tetap Tahun 2020 terdiri dari biaya penyusutan kandang sebesar Rp 362.138,00:, biaya penyusutan peralatan sebesar Rp 25.819 dan biaya listrik sebesar Rp 30.875. Total biaya tetap sebesar Rp 418.832 .

Tabel 2. Analisis Pendapatan Peternakan Sapi Potong Rakyat Kabupaten Langkat

\begin{tabular}{|c|c|c|c|c|}
\hline \multirow{2}{*}{ No } & \multirow{2}{*}{ Keterangan } & \multicolumn{3}{|c|}{ Tahun } \\
\hline & & 2018 & 2019 & 2020 \\
\hline \multirow[t]{2}{*}{1} & Penerimaan & & & \\
\hline & Penjualan Ternak & $5.037 .500,000$ & $11.900 .000,00$ & $16.122 .500,00$ \\
\hline \multirow[t]{11}{*}{2} & Biaya Produksi & & & \\
\hline & Biaya Tetap & & & \\
\hline & Penyusutan Kandang & $362.138,00$ & $362.138,00$ & $362.138,00$ \\
\hline & Pemyusutan Peralatan & $25.819,00$ & $25.819,00$ & $25.819,00$ \\
\hline & Biaya Listrik & $24.875,00$ & $27.875,00$ & $30.875,00$ \\
\hline & Total Biaya Tetap & $412.832,00$ & $415.832,00$ & $418.832,00$ \\
\hline & Biaya Tidak Tetap & & & \\
\hline & Pakan & $867.375,00$ & $2.880 .900,00$ & $4.131 .000,00$ \\
\hline & Inseminasi Buatan & $93.437,50$ & $294.750,00$ & $423.750,00$ \\
\hline & Total Biaya Tidak Tetap & $960.812,50$ & $3.175 .650,00$ & $4.554 .750,00$ \\
\hline & Total Biaya Produksi & $1.379 .643,50$ & $3.591 .481,25$ & $4.967 .581,25$ \\
\hline
\end{tabular}

3 Pendapatan

3.657.856,50

8.305.519,00

11.148.919,00

Sumber : Data Olah Primer 2020

Biaya tidak tetap terdiri dari biaya pakan dan inseminasi buatan. Biaya Tidak Tetap Tahun 2018 adalah biaya pakan sebesar Rp 867.375,00 dan biaya inseminasi buatan sebesar Rp 93.437,00. Total Biaya Tidak Tetap sebesar Rp 960.812,50. Biaya tidak tetap 2019 terdiri dari biaya pakan dan inseminasi buatan. Biaya Tidak Tetap Tahun 2019 adalah biaya pakan sebesar Rp 2.880.900,00 dan biaya inseminasi buatan sebesar Rp 294.750,00. Total Biaya Tidak Tetap sebesar Rp 3.175.650,00. Biaya tidak tetap 2020 terdiri dari biaya pakan dan inseminasi buatan. Biaya Tidak Tetap Tahun 2020 adalah biaya pakan sebesar Rp 4.131.000,00 dan biaya inseminasi buatan sebesar Rp 423.750,00. Total Biaya Tidak Tetap sebesar Rp 4.554.750. Biaya produksi terbesar adalah biaya pakan. Berdasarkan penelitian Hastang dan Aslina (2014) menyatakan bahwa biaya pakan merupakan komponen biaya besar dalam usaha peternakan.

Pendapatan merupakan selisih dari total penerimaan dengan total biaya yang dikeluarkan dalam melakukan suatu usaha. Berdasarkan penelitian Haloho (2020) menyatakan bahwa Pendapatan merupakan suatu penerimaan dikurangi biaya produksi maka hasilnya dinyatakan dengan keuntungan/kerugian. Pada usaha ternak sapi potong diperoleh dari hasil penerimaan usaha sapi potong dikurangi dengan total biaya yang dikeluarkan. Jika nilai yang diperoleh positif, maka dapat dikatakan bahwa usaha tersebut memperoleh keuntungan sedangkan apabila diperoleh hasil negatif maka dapat dikatakan bahwa usaha yang dilaksanakan tidak memperoleh keuntungan/rugi.Pendapatan Tahun 2018 diperoleh sebesar Rp 3.657.856,50. Pendapatan 
Tahun 2019 diperoleh sebesar Rp. 8.305.519,00. Pendapatan Tahun 2020 diperoleh sebesar Rp $11.148 .919,00$.

\subsubsection{Analisis Kelayakan Usaha Ternak Sapi Potong Rakyat}

Analisis kelayakan yang digunakan untuk mengetahui kelayakan usaha tani ternak sapi potong ini adalah ROI ,NPV, BCR dan IRR. Adapun analisis usaha ternak sapi potong dapat dilihat pada Tabel 3

Tabel 3. Analisis Usaha Peternakan Sapi Potong Rakyat Kabupaten Langkat

\begin{tabular}{ccc}
\hline No & Keterangan & Jumah \\
\hline 1 & ROI & $27,45 \%$ \\
2 & NPV & $\operatorname{Rp~} 452.758$ \\
3 & BCR & 1,01 \\
4 & IRR & 14,05 \\
\hline
\end{tabular}

Menganalisis aspek finansial dari analisis kelayakan usaha adalah untuk menentukan rencana investasi melalui perhitungan biaya dan manfaat yang diharapkan dengan membandingkan antara biaya produksi dan pendapatan. Analisis kelayakan usaha yang akan dihitung untuk mengetahui usaha tersebut layak atau tidak untuk dijalankan adalah ROI, NPV BCR dan IRR (Parlindungan et al., 2017)

1. ROI (Return Of Investment)

Berdasarkan Tabel 3 dapat diketahui nilai ROI yang diperoleh dari usaha ternak sapi potong rakyat di Kabupaten Langkat sebesar 27,45\% Nilai ROI 27,45\% lebih besar dari tingkat suku bunga deposito Bank BRI Tahun 2020 yaitu sebesar 4\% sehingga usaha sapi perah layak untuk beroperasi. ROI > dari tingkat suku bunga bank, maka usaha layak untuk dilaksanakan. Berdasarkan Penelitian Haloho (2020) menyatakan bahwa ROI 27,45\% > dari suku bunga Bank dan usaha sapi potong tersebut layak dijalankan. Hasil penelitian Putri et al. (2018) menyatakan bahwa profitablitas usaha penggemukan sapi potong di Kabupaten Semarang lebih tinggi dari tingkat suku bunga deposito Bank dan menguntungkan. Menurut Budirahardjo et al. (2011) bahwa nilai profitabilitas yang lebih besar dari suku bunga bank dapat dinyatakan usaha tersebut layak dilakukan karena mampu menghasilkan keuntungan

2. NPV

NPV yang diperoleh sebesar Rp 452.758 yang berarti bahwa keuntungan yang diperoleh lebih besar daripada biaya produksi ditambah investasi. NPV positif berarti usaha tersebut menghasilkan lebih banyak benefit yang diterima daripada biaya yang dikeluarkan. NPV lebih besar dari 0 maka usaha dikatakan layak. Hal ini sesuai dengan penelitian Haloho (2020) menyatakan bahwa analisis kelayakan sapi potong NPV > O maka usaha dikatakan layak.

3. BCR

BCR yang diperoleh sebesar 1,01 menunjukkan bahwa setiap tambahan biaya yang dikeluarkan sebesar Rp 1 akan menghasilkan tambahan manfaat bersih bagi usaha peternakan sapi potong sebesar Rp 1,01. Nilai BCR >1 menunjukkan usaha layak untuk dijalankan. Hasil penelitian Lestari et al. (2015) yang menyatakan bahwa usaha penggemukkan sapi potong layak diusahakan karena peternak mendapatkan keuntungan dari usaha tersebut.

4. IRR

IRR yang diperoleh sebesar $14,05 \%$ Nilai IRR tersebut berarti bahwa pada tingkat bunga kredit bank tersebut (6\%) nilai NPV sama dengan 0 . Nilai IRR yang lebih besar dari tingkat bunga kredit bank BRI sebesar 4\% sehingga usaha penggemukan sapi potong di Kabupaten Langkat layak untuk diusahakan. Hasil penelitaian Steflyando (2014) yang menyatakan bahwa usaha penggemukan sapi potong dengan IRR sebesar 12,3\% lebih besar dari bunga kredit Bank layak dijalankan. Berdasarkan penelitian Haloho (2020) menyatakan bahwa usaha penggemukkan sapi potong di Kecamatan Binjai Barat sebesar 22,32\% layak untuk dijalankan.

\section{Simpulan}

Usaha Sapi Potong Rakyat di Kabupaten Langkat layak untuk dijalankan dengan hasil perhitungan ROI sebesar 27,45\% lebih besar dari pada tingkat bunga depositi Bank BRI sebesar 4\%. NPV sebesar Rp Rp 452.758 bernilai lebih besar dari Nol. Nilai Net BC ratio 1,01 lebih besar dari 1. IRR yang diperoleh sebesar 14,05\% lebih besar dari tingkat bunga kredit bank BRI sebesar $6 \%$. Karakteristik peternak yaitu usia peternak berusia produktif yaitu 40-50 Tahun (47 orang), tingkat pendidikan peternak sebagian besar berpendidikan Sekolah Menengah Pertama 48,75\% dan Pengalaman beternak yaitu 11-20 Tahun sebanyak 51 orang $(63,75 \%)$. 


\section{Pustaka}

Anis, S.D., E. Wantasen., S. Dalie., D. A Kaligis and U. Paputungan. 2015. Beef cattle feasibility study of house hold farm in Bolmong Regency, North Sulawesi Province of Indonesia. International Journal of Agricultural Sciences and Natural Resources. 2 (2) : 36-39

Budiraharjo, K., M.Handayani dan G. Sanyoto. 2011. Analisis Profitabilitas Usaha Point Penggemukan Sapi Potong Di Kecamatan Gunungpati Kota Semarang. Mediagro. 7 (1):19.

Dinas peternakan dan kesehatan hewan. 2018. Kementerian Pertanian Direktorat Jenderal Peternakan dan Kesehatan Hewan. http://ditjenpkh.pertanian.go.id. Di akses 07 Juli 2019

Direktorat Dinas Ketahanan Pangan dan Peternakan Provinsi Sumatera Utara. 2019. http://dishanpangternak.sumutprov.go.id/. Diakses 08 Agustus 2020

Eddy, B. T., Roessali, W., \& Marzuki, S. 2012. Dairy cattle farmers' behaviour and factors affecting the effort to enhance the economic of scale at Getasan District, Semarang Regency. Journal of the Indonesian Tropical Animal Agriculture. 37 (3): 20-22

Haloho, R. D. 2020. Analisis Usaha Penggemukan Sapi Potong Dengan Menggunakan Paradigma Agribisnis (Studi Kasus Pada Peternakan Sapi Potong Molan) di Kecamatan Binjai Barat Kota Binjai Provinsi Sumatera Utara. Agrimor. 5:17-19.

Haloho, R.D. 2020. Analisis Kelayakan Usaha Penggemukan Sapi Potong Molan Kecamatan Binjai Barat Kota Binjai. Jurnal Penelitian Peternakan Terpadu. 22 (2) : 1-8

Hasibuan, M. I. A., \& Meneth Ginting, E. 2014. Analisis Usaha Ternak Sapi Potong (Studi Kasus: Desa Ara Condong, Kecamatan Stabat, Kabupaten Langkat). Journal on Social Economic of Agriculture and Agribusiness.

Hastang, \& Asnawi, A. 2014. Analisis Keuntungan Peternak Sapi Potong Berbasis Peternakan Rakyat Di Kabupaten Bone Profit Analysis Of Cattle Farms Based on Rural Farm in Bone Regency. Jurnal Ilmiah Ilmu-Ilmu Peternakan. 1 (1): 240-252

Idin, L. 2016. Analisis produktivitas tenaga kerja pada pengolahan kopra di kota raha. Ekonomi. https://doi.org/10.1074/jbc.M108014200

Lestari, R. D., Baga, L. M., \& Nurmalina, R. (2015). Analisis Keuntungan Finansial Usaha Penggemukan Sapi Potong di Kabupaten Bojonegoro. SEPA: Jurnal Sosial Ekonomi Pertanian dan Agribisnis, $11(2), 207-215$.

Otoluwa, M. A., Salendu, A. H. ., Rintjap, A. K., \& Massie, M. T. 2015. Prospek Pengembangan Usaha Ternak Sapi Potong Di Kecamatan Bolangitang Timur Kabupaten Bolaang Mongondow Utara. Zootec.36 (1): 191-197

Parlindungan, MD., A.Yusdiarta dan H. Miftah. 2017. Analisis Kelayakan Finansial Peningkatan Kapasitas Produksi Sapi Potong. 2017. Jurnal Pertanian 8 (2) : 113-120

Putri, G, N., D. Sumarjono dan W. Roessali. 2019. Analisis Pendapatan Usaha Sapi Potong Pola Penggemukkan Pada Anggota Kelompok Tani Ternak Bangunrejo II Di Desa Polosiri Kecamatan Bawen Kabupaten Semarang. Agrisocionomics. 3 (1): 39-49

Sahala, J. R. Widiati dan E. Baliarti. 2016. Analisis Kelayakan Finansial Usaha Penggemukan Sapi Simmental Peranakan Ongole Dan Faktor-Faktor Yang Berpengaruh Terhadap Jumlah Kepemilikan Pada Peternakan Rakyat Di Kabupaten Karanganyar. Buletin Peternakan .40 (1): 75-82

Setiadi, A., Santoso, S. I., Nuswantara, L. K., \& Sunarso. 2012. Some factors influencing the income of kaligesing goat farmers in Borobudur subdistrict, magelang regency, Central Java, Indonesia. Journal of the Indonesian Tropical Animal Agriculture. 37 (4) : 308-313

Soekardono. 2009. Ekonomi Agribisnis Peternakan Teori dan Aplikasinya, Akademika Pressindo, Jakarta

Sunarto, E., O. H. Nono., U. R. Lolea, dan H.Y. Sikone. 2016. Analisis Finansial Sistim Penggemukan Sapi Potong oleh Perusahaan dan Peternakan Rakyat di Kabupaten Kupang. Journal of Animal Science. 1 (4) : 46-4.

Steflyando, R., Abubakar dan A. Sale. 2014. Analisis Kelayakan Usaha Sapi Potong Dengan Metode Zero Waste Farming Di Kecamatan Parongpong. Jurnal Teknik Industri Itenas. 4 (1): 226-237.

Widayati, T. W., Santoso, B., Woran, D., Warsono, I. U., \& Palulungan, J. A. (2018). Feasibility Study on Beef Cattle Development in Teluk Bintuni Regency, West Papua. Buletin Peternakan. 42(2): 170-178 